\title{
INDONESIA SEBAGAI NEGARA HUKUM
}

\author{
Sarudi \\ Fakultas Hukum UMM Mataram \\ Email korespondensi: rudisarudi63@gmail.com
}

\begin{abstract}
ABSTRAK
Lemahnya penegakan hukum dalam negara hukum Indonesia merupakan suatu ciri negara yang sedang berkembang masih mencari bentuk sendiri. Untuk menciptakan pembangunan yang efektif dan pemerintah yang bersih berdasarkan supremasi hukum dengan meningkatkan kemampuan dan wibawa penegak hukum di samping menertibkan fungsi lembaga-lembaga hukum menurut proporsinya masing-masing. Pemupukan kesadaran hukum dalam masyarakat dan membina sikap para penguasa dan para pejabat pemerintah kearah penegakan hukum keadilan serta perlindungan terhadap harkat dan martabat manusia dan ketertiban serta kepastian hukum sesuai dengan UUD 1945.

Pembangunan dibidang hukum negara hukum Indoensia didasarkan atas landasan tertib hukum seperti yang terkandung dalam Pancasila dan UUD 1945. Pembangunan dan pembinaan hukum diarahkan agar hukum mampu memenuhi kebutuhan sesuai dengan tingkat kemajuan pembangunan di segala bidang sehingga dapat diciptakan ketertiban dan kepastian hukum dan memperlancar pelaksanaan pembangunan.
\end{abstract}

Kata Kunci : untuk menciptakan pembangunan yang efektif, bersih dan berwibawa dapat dicapai dengan menjunjung supremasi hukum sebagai syarat tegaknya negara hukum

\begin{abstract}
Strafraigtening sentences in politic state Indonesian to constitute a state characteristic that amends is still look for alone form. As to establish development which effective and commanding clear one bases rule of law by increase ability and enforcer authority sentence beside disciplinize institute function sentence to terminological its proportion each. Consciousness dunging sentences in society and builds attitude power and government officials to aim strafraigtening justice and protection law to degree and man and orderliness dignity and rule of law corresponds to UUD 1945.

Development at bodies politic jurisdictional area Indoensia is gone upon base up rule of law as one consists in Pancasila and UUD 1945. Development and law construction is led that law can meet the need to correspond to forward zoom development at all area so gets to be created by orderliness and rule of law and smooths development performing.
\end{abstract}

Keyword: as to establish development which effective, clean slate and gets authority can be reached by on the up rule of law as requisite of its straightening bodypolitic 


\section{PENDAHULUAN}

\section{Latar Belakang}

Pada zaman Majapahit sudah mengenal hukum pada saat itu dipergunakan istilah Dharmanegara atau Negara Dharma untuk menyatakan pengertian negara hukum. Kata dharma menunjukkan bahwa negara itu mempunyai tugas kewajiban hukum waktu itu. Jadi Indonesia negara hukum merupakan warisan dari nenek moyang bangsa Indonesia yang sudah berabad-abad lamanya.

Kewajiban negara hukum itu dinamai Negara Dharma - Wicesa, yang merupakan peraturan hukum yang turun temurun yang berlaku sejak zaman leluhur dan menjadi dasar bagi negara hukum atau dharma negara. Masuk ke dalam peraturan hukum terutama hukum-hukum kebiasaan yang berlaku dan segala peraturan agama yang menjadi pedoman hidup bagi peraturan kesusilaan dalam negara dan masyarakat.

Pengertian hukum atau kaidah hukum tersirat dalam kata-kata bahasa Jawa"Angger-angger dan Uger" yang dalam bahasa Indonesia menjadi anggaran dan Ugaran (norma), (Prof. Mr. H. Muh. Yamin, Naskah Persiapan Undang-undang Dasar 1945 Jilid III, Th.1 960).

Dalam Konstitusi Indonesia tahun 1949 - 1950 Istilah Indonesia negara hukum resmi dipakai. Dalam kepustakaan hukum Eropa Barat, yang berbahasa Inggris dipergunakan istilah rule of law atau government of justice untuk menyatakan negara hukum.

Dalam kedua istilah ini tidak terselip perkataan (state), melainkan syarat peraturan hukum itu dihubungkan kepada pengertian kekuasaan (ade) atau pemeintah (government). Juga pengertian hukum itu dilahirkan dengan laq (peraturan) atau justice (keadilan). Kedua paham law atau justice memang ada persamaannya, karena beisi peraturan yang harus dipatuhi, tetapi juga ada perbedaannya yang menunjukkan dalam hal terhadap justice adalah dalam rangka yang lebih luas dan lebih tinggi, sesuai dengan pengertian adil yang didalamnya juga mengandung bayangan keagamaan yang bersumber pada kepercayaan Tuhan Yang Maha Kuasa. Dapat kita menimba pengalaman dari uraian di atas bahwa ajaran sarjana hukum Jhon Locke dan Mantesquicu yang terkenal dengan Trias Politikkannya tentang pembagian kekuasaan (sparation atau division of power) telah dijalankan oleh negara-negara Indonesia waktu itu seperti Srwijaya, Majapahit, Melayu, Minangkabau.

Pembagian kekuasaan dalam negara Indonesia bersumber dalam ketatanegaraan Indonesia. Oleh karena itu ajaran trias Politika merupakan cangkolan asing tambahan Indonesia. Pada kenyataannya bahwa segala peraturan negara bersumber kepada proklamasi kemerdekaan Indonesia dapat dibagi atas jenis peraturan-peraturan tertulis menurut jawatan-jawatan lain yang berdasarkan peraturan tertulis. Instansi-instansi tersebut semuanya tercantum dalam UU Dasar Proklamasi yaitu UUD 1945.

Salah satu tujuan pembangunan nasional adalah untuk menciptakan pembangunan yang efektif, bersih dan berwibawa serta menjunjung supremasi hukum untuk terwujudnya penyelenggaraan pemerintahan yang menegakkan hukum di tengah kehidupan bermasyarakat dan bernegara.

Oleh karena itu semua peraturan negara Republik Indonesia sebagai negara hukum langsung atau tidak langsung bersumber kepada kemerdekaan Bangsa 
Indonesia yang diproklamasikan tanggal 17 Agustus 1945 termasuk juga UUD Proklamasi tanggal 17 tahun 1945 didalamnya.

\section{Rumusan Masalah}

1. Apa yang dimaksud dengan Indonesia Sebagai Negara Hukum?

2. Apa saja yang menjadi paradigma Indonesia Sebagai Negara Hukum?

3. Apa saja yang menjadi indikator Indonesia Sebagai Negara Hukum?

\section{METODE PENELITIAN}

Metode yang digunakan adalah metode kualitatif. Menurut Melong, 1997, penelitian dengan pendekatan kualitatif mengandung karakteristik yaitu; berakar pada latar alamiah sebagai keutuhan, mengandalkan manusia sebagai alat penelitian, memanfaatkan metode kualitatif mengadakan analisis data secara induktif, bersifat deskriptif, lebih mementingkan proses dari hasil, membatasi studi dengan fokus, memiliki seperangkat kriteria untuk memeriksa keabsahan data, rancangan penelitian bersifat sementara dan hasil penelitiannya disepakati oleh kedua belah pihak, peneliti dan diteliti.

Penelitian kualitatif adalah penelitian dengan paradigma naturalistik, menurut Muhadjir, 2000;45, menuntut dilaksanakannya penelitian dalam konteks natural, dengan harapan makna yang diangkat dari penelitian memang dari konteksnya dari prakonsep penelitiannya.

Sedangkan jenis penelitian ini adalah menggambarkan tentang fenomena Indonesia sebagai negara hukum. Dalam penelitian ini penulisan menggunakan library resep/penelitian kepustakaan dengan mengumpulkan buku-buku/karangan yang berkaitan dengan judul penelitian yang selanjutnya melakukan indentifikasi terhadap substansi judul penelitian Indonesia sebagai negara hukum.

\section{HASIL DAN PEMBAHASAN \\ Tinjauan Sosiologi}

Sesuai dengan latar belakang disebutkan bahwa negara hukum Indonesia merupakan warisan nenek moyang bangsa Indonesia kalimat ini bukanlah berati bahwa negara hukum sama dengan negara adat atau hukum agama, dan sangat berbeda dengan negara kekuasaan atau negara polisi.

Bila ditinjau dari aspek sosiologis bahwa Indonesia sejak dahulu telah mengalami telah mengalami evolusi masyarakat dari masa ke masa dengan bentuk kesatuan masyarakat yang berbeda-beda baik zaman sebelum kerajaan, kerajaan, zaman penjajahan sampai pintu gerbang Indonesia sebagai tonggak Indonesia merdeka 17 Agustus sebagai awal dimulainya pemerintahan negara yang berdasarkan hukum sebagai panglima tertinggi dalam penyelenggaraan pemerintahan yang berdasarkan UUD 1945. Karena negara hukum Indonesia, terdapat dalam kalimat kata pembukaan UUD 1945 yang berbunyi "maka disusunlah kemerdekaan Indonesia itu dalam suatu Undang-undang Dasar Negara Indonesia". Jadi tumbuh tegas bahwa sumber hukum yang memancarkan segala peraturan negara ialah proklamasi kemerdekaan 1945 sendiri, sejak hari proklamasi maka mulailah perkembangan hukum nasional tertulis.

Artinya semenjak tanggal 17 Aguatus 1945 proklamasi susunan ketatanegaraan Republik Indonesia tidak lagi dibentuk atas susunan penjajahan/kolonial/kerajaan, melainkan semata-mata disusun atas kemerdekaan nasional yang berdaulat penuh. Untuk selanjutnya hukum adat dan peraturan agama 
atau hukum kolonial masih berlaku dalam zaman peralihan, maka berlakunya itu adalah hanya dengan kekuatan suatu peraturan tertulis. Konstitusi Republik Indonesia 1945 adalah konstitusi penyusunan kemerdekaan nasional yang pertama kali dengan tertulis, dimana Undang-undang Dasar 1945 merupakan fundamental law Republik Indonesia.

Negara Indonesia di zaman dahulu, misalnya Kerajaan Majapahit, Airl angga, Kedatuan Siwijaya, negara Melayu-Minangkabau, Mataram Penjajaran dan Aceh dan semuanya menurut ketatanegaraan hukum kebiasaan yang sebagian besar atau seluruhnya tidak tertulis dalam suatu buku kodifikasi walaupun ditinjau dari sudut sejarah memang dapat berlaku atau bertahan lama.

Hal ini juga dapat menunjukkan dasar-dasar hukum Republik Indonesia menurut UUD 1945 memang sesuai dengan syarat-syarat kepribadian dan peradaban bangsa Indonesia, dengan hawa iklim dan tinjauan hidup nasional.

Di dalamnya terdapat unsur kemenangan segala revolusi sedunia dan menjadi pendorong revolusi Indonesia.

Dengan demikian maka UUD 1945 tidaklah mengenai ajaran-ajaran Trias Politika yang membagi tugas pekerjaan pemerintahan atau perlengkapan negara menjadi tiga buah perlengkapan (organ) atau tiga buah

jawaban (fungsi). Tetapi UUD 1945 dengan tegas melaksanakan pembagian

pekerjaan pemerintahan atau perlengkapan negara atas pelaksanaan dasar beberapa pembagian atau pemisahan kekuasaan (division atau separation of powers) dengan tujuan untuk kelancaran pekerjaan dan untuk perlindungan warga negara Indonesia sebagai negara hukum.

Pembagian kekuasaan ini adalah sesuai dengan kebudayaan pribadi bangsa Indonesia di bidang penyusunan ketatanegaraan nasional, sepeti ternyata dalam negara Indonesia yang merdeka dan berdaulat di sepanjang masa.

Penyusunan ketatanegaraan yang bersumber pada proklamasi kemerdekaan Indonesia tahun 1945 itu adalah pelaksanaan kemerdekaan dalam tatanan hukum konstitusional dengan menurut tuntutan modern di Indonesia sejak revolusirevolusi di belahan dunia sampai merdeka tahun 1945. Pembagian kekuasaan pemerintah berlangsung dalam kesatuan pemerintah yang bulat dan semata-mata untuk memperteguh persatuan dan kekompakan dalam negara kesatuan dengan menjamin kelancaran administrasi dan kebebasan rakyat Indonesia.

Jadi pembagian kekuasaan adalah untuk memberantas perpecahan dalam masyarakat dan untuk menjamin kesatuan tindakan dalam negara Republik Indonesia, yang tidak mengenal pemusatan kekuasaan dalam satu langgan, melainkan mewujudkan kesatuan dan persatuan nasional dalam Republik Indonesia yang pada waktu itu untuk mempertahankan kemerdekaan.

Republik Indonesia adalah suatu negara hukum, sehingga Undang-undang Dasarnya dan segala peraturan-peraturan negara sewajarnyalah harus bersumber kepada kemerdekaan nasional, yang sudah dituangkan di dalam UUD 1945 yang terdiri dari pembukaan, batang tubuh, 37 ayat 4 aturan peralihan dan dua ayat aturan tambahan berikut penjelasan-penjelasannya. Sistem pemerintahan negara yang ditugaskan dalam UUD, bahwa Indonesia ialah negara yang berdasar atas hukum (Rechts staat), tidak berdasarkan kekuasaan belaka (matchs staat). Pemerintahan berdasar atas sistem konstitusi (hukum dasar) tidak bersifat absolutisme (kekuasaan yang tidak terbatas). 


\section{Praktik Penegakan Hukum}

\section{Ciri-ciri Negara Hukum}

Salah seorang sarjana dari Jerman yang dianggap berjasa mengemukakan pendapatnya mengenai konsep negara hukum ialah F.J. Stahl, dengan semboyannya bahwa "negara harus menjadi negara hukum", semboyannya mi menjadi pendorong perkembangan zaman baru.

- Negara harus menentukan secermat-cermatnya jalan-jalan dan batas-batas kegiatannya sebagai lingkungan (suasana) kebebasan warga negara menurut itu dan harus menjamin suasana kebebasan itu tanpa dapat ditembus.

- Negara harus mewujudkan atau memaksakan gagasan akhlak dari segi negara, juga secara langsung tidak jauh dari pada seharusnya menurut suasana hukum.

Semboyan F.J. Stahl ini merupakan suatu filsafat yang perlu kita renungkan bahwa siapa yang tidak rindu dengan tegaknya keadilan dalam perlakuan di muka hukum.

Karena dengan adanya keadilan yang diperlakukan rakyat tentunya akan dirasakan kemanfaatan perlakuan dari pemerintah.

Sehingga rakyat merasa terlindungi dan dijamin hak asasinya. Tata tertib menurut hukum harus benar-benar dijalankan asalkan hukum yang diberlakukan kepada rakyat tidak bertentangan dengan hak asasi manusia. Karena pada prinsipnya hak asasi manusia harus benar-benar diperhatikan, dan dilindungi dengan menjamin kebebasan sesuai dengan norma hukum yang berlaku.

Menurut F.J. Stahl, unsur-unsur negara hukum adalah :

a. Adanya jaminan terhadap hak asasi manusia (Grandrechten)

b. Adanya pembagian kekuasaan (Scheiding Van Matchten)

c. Pemerintahan haruslah berdasarkan peraturan-peraturan hukum (Wet Matigheid Van Met Bestuur)

d. Adanya peradilan administrasi (Administratief Rechtspraak)

Sedangkan Paul Schalten menyebutkan cii negara, yang kemudian diuraikannya secara meluas dan kritis.

Adapun ciri-cirinya adalah :

a. Kawula negara itu mempunyai hak terhadap negara, individu mempunyai hak terhadap masyarakat.

b. Di dalam negara hukum ada pemisahan di dalam kekuasaan.

Dengan pendapat Paul Schalten sudah jelas menginginkan supremasi aturan-aturan hukum (supremacy of law). Dengan tidak ada kekuasaan yang sewenang-wenang dari penguasa (absolutisme) di hadapan hukum kedudukan warga negara sama baik warga atau pejabat, terjaminnya hak-hak manusia oleh undang-undang.

1. Sistem Pemerintahan Negara

Sistem pemerintahan negara ditegaskan dalam Undang-undang Dasar Negara Republik Indonesia tahun 1945 (UUD 1945) dimana merupakan amanat yang sangat mulia untuk dilaksanakan. Indonesia adalah negara yang berdasarkan asas hukum (rechts staat), tidak berdasarkan atas kekuasaan belaka (machts staat). 
Didalam praktiknya sangat mengecewakan rakyat, kekecewaan atas lemahnya penegakan hukum karena apa yang seharusnya dalam hukum ternyata non-sense dalam kenyataan. Hal ini disebabkan karena intervensi politik yang sangat dominan, disamping realitasnya hukum adalah produk politik. Bangsa Indonesia yang sudah merdeka setengah abad lebih belum merasakan kesejahteraan yang sebenarnya, situasi dan kondisi yang sangat tergantung bagaimana proses politik yang terjadi dibalik perbuatan resmi tentang hukum. Indonesia negara hukum dinilai oleh rakyat bagaimana implementasi hukum di lapangan. Penilaian rakyat hanya terbatas asumsiasumsi mengenai hubungan politik dan hukum yang berkembang selama ini asumsi itu tidak ada yang salah dan kenyataan tidak ada yang benar, hanya sekedar pilihan.

2. Hukum determinan atas politik.

Hal ini merupakan suatu dambaan bangsa Indonesia karena di dalam pembukaan UUD 1945 "melindungi segenap bangsa Indonesia dan seluruh tumpah darah Indonesia dengan berdasar atas persatuan dengan mewujudkan keadilan sosial bagi seluruh rakyat Indonesia".

3. Hal ini tidaklah pernah terwujud dalam negara hukum Indonesia.

Aliran pengertian negara persatuan kenyataannya terpecah belah konflik berkepanjangan hampir semua di provinsi porak-poranda sepeti Maluku, Aceh, Papua, Sampit, Poso bahkan Timor Timur yang sudah di bangun dengan modal tenaga, pikiran, keringat bahkan dengan ribuan nyawa dicaplok lagi oleh politik negara adikuasa. Kasus-kasus HAM, KKN tidak ada yang diselesaikan konsep kemakmuran dan kesejahteraan yang tercermin dalam keadilan dalam perlakuan terhadap hukum belum terwujud, Belum mampu mengubah kemiskinan menjadi makmur, kehidupan dimana rakyat mendapat kebahagiaan jasmani dan rohani akibat terpenuhinya kebutuhan-kebutuhan hidupnya dan terjaminnya keamanan, keselamatan. ketenteraman kesenangan hidupnya, tidak kurang suatu apapun.

a. Politik determinan atas hukum

Ini merupakan das sein, sehingga hukum di Indonesia sulit ditegakkan karena kadang-kadang suatu keputusan penguasa tidak bisa dilaksanakan karena tidak mendapat dukungan politik. Pemerintah dalam hal ini bisa berhenti ditengah jalan dai jabatan presiden apabila sudah tidak mendapat dukungan politik. Salah satu contoh pada waktu pemerintah Soekarno bahwa Dekrit pada 5 Juli 1959 berjalan dengan mulus karena mendapat dukungan politik dari Rakyat plus ABRI. Sedang pada zaman presiden Gusdur keputusannya banyak yang tidak dapat dilaksanakan karena tidak mendapat dukungan politis dai rakyat dan ABRI.

- Gusdur mengeluarkan Dekrit

- Gusdur mengeluarkan Keppres memecah Kapolri dimana Polri pada waktu itu tidak mau tunduk kepada keputusan Presiden.

Ini adalah salah satu bukti bahwa di dalam suatu negara hukum dimana penegakan hukum belum berjalan sebagaimana mestinya karena tidak mendapat dukungan politik dan rakyat/ABRI. 
b. Yang baik sebenarnya adalah bahwa dalam suatu negara hukum antara hukum dan politik seharusnya interdependen (das sallen das sein) saling melengkapi. Karena pada praktiknya das sallen dan das sein itu pasti ada secara bersamaan didalam segala bidang kehidupan manusia sebagai dunia "teori" dan dunia praktik atau dunia kenyataan, yang akan selalu saling melengkapi dan saling mengisi satu sama lain.

Demikian pula tentunya dalam bidang segala ilmu dan teori hukum yang pertama dipelajari oleh calon sarjana hukum atau para peminat pengetahuan hukum semuanya itu adalah bentuk-bentuk yang langsung dari das sallen, sedangkan praktik/pelaksanaan atas pencerapan hukumnya sendiri itulah yang bam termasuk das sein. Karena hukum itu sendiri merupakan peraturan-peraturan, baik yang tertulis maupun tidak tertulis yang pada dasarnya berlaku dan diakui orang yang harus ditaati dalam hidup bermasyarakat. Masyarakat yang akan diatur oleh hukum adalah sekelompok orang tertentu yang mendiami suatu daerah tertentu dan tunduk pada peraturan hukum tertentu.

Mewujudkan penegakan hukum yang adil bagi semua pihak tanpa pengecualian, menjunjung tinggi HAM dan memperhatikan nilai-nilai hidup dalam masyarakat salah satu prinsip dan pada pemerintahan yang baik. Disamping mampu mendorong memotivasi setiap warga untuk berpartisipasi mempergunakan hak dalam menyampaikan keputusan yang menyangkut kepentingan masyarakat, baik secara langsung maupun tidak langsung. Dengan demikian akan dapat menanamkan kepercayaan timbal balik antara pemerintah dan masyarakat dengan ini memberikan peluang sama bagi setiap anggota masyarakat untuk meningkatkan kesejahteraannya.

Asas kekeluargaan dalam pasal banyak. 33 UUD 1945 kemakmuran masyarakat yang diutamakan bukan kemakmuran orang seorang, namun orang seorang boleh berusaha sejauh tidak mengenai hajat hidup orang Negara Indonesia sebagai negara hukum apabila bercermin kepada UUD 1945 maka hukum di sini tidak lain adalah sebagai wahana untuk menyelenggarakan kehidupan negara atau ketertiban dan menyelenggarakan kesejahteraan sosial.

Jadi hukum ialah wahana untuk tata "Tenterem Kata Raharja", jadi bukan sekedar untuk Kamtibmas.

Asas kekeluargaan didalam UUD 1945 tercermin dalam pasal pasal baik yang hanya mengenai warga negara maupun yang pasal baik yang hanya mengenai warga negara maupun yang mengenai seluruh penduduk yang bersifat demokratis dan yang hendak menyelenggarakan keadilan sosial dan perikemanusiaan. Menegakkan demokrasi yang intinya didalam UUD 1945 dijelaskan dengan rumusan tujuan pokok sistem pemerintahan negara berkeadilan sosial yang dijelaskan pada pasal 33 UUD 1945, sedangkan perikemanusiaan atau menegakkan perikemanusiaan yang didalam pokok pikiran yang terkandung di dalam pembukaan didasarkan kepada Ketuhanan Yang Maha Esa dan dilaksanakan secara adil dan beradab.

Adapun fungsi hukum sebagai pengayoman yang digambarkan dengan pohon pengayoman maka visualisasi hukum dan keadilan ini 
berbeda dengan negara yang sistem pemerintahannya yang liberal dimana hukum dan keadilan digambarkan sebagai Dewi Yustisia yang memegang pedang. Negara dianggap sebagai hasil perjanjian masyarakat dari pada individu yang bebas.

Status yang kita sebut bernegara merupakan hasil usaha manusia untuk meningkatkan dirinya dari status alam (status naluralis) dengan hukum imbasnya ke status bernegara (status civil) dengan perlindungan atas hak asasinya (civil rights). Berpangkal pada manusia dilahirkan dalam hubungannya atau keberadaannya dengan orang lain. Sehingga negara bukan terbentuk atas perjanjian melainkan berkat rahmat Allah yang maha kuasa dengan didorongkan oleh keinginan luhur yang maha kuasa dengan didorongkan oleh keinginan luhur supaya berkehidupan kebangsaan yang bebas. Asas kekeluargaan merupakan suatu kesepakatan satu tujuan.

Disamping itu sesuai rumusan didalam alinea II pembukaan UUD 1945 disebutkan bahwa bangsa Indonesia mencitrakan keadaan yang merdeka, berdaulat, adil dan makmur.

Prinsip-prinsip Yuridis Formal

Alinea II pembukaan UUD 1945 inilah fokus daripada operasionalisasi negara hukum Indonesia yang tidak bisa lepas dari siklus perkembangan politik hukum, pembangunan hukum dan perkembangan hukum itu sendiri.

1. Hukum itu merupakan produk politik oleh karena itu hukum harus dibentuk (pembentukan hukum).

2. Tujuan hukum itu untuk mencapai kepastian, keadilan, kemanfaatan oleh karena itu hukum diterapkan sehingga ada pelayanan hukum.

3. Karena hukum itu harus benar-benar ditegakkan agar mencapai keadilan dalam pelayanan hukum maka oleh karena itu hukum banyak hambatanhambatan didalam penerapannya.

4. Hukum itu harus mendapat dukungan politik sesuai dengan berlaku secara arif dan bijaksana dengan demikian sangat terganggu pada kondisi dan situasi politik.

Oleh karena itu hukum harus dikembangkan sesuai dengan perkembangan masyarakat dan perkembangan teknologi dan ilmu pengetahuan. Keempat prinsip dapat dilaksanakan dengan memperhatikan asas negara hukum yaitu asas legalilas, asas ini sangat bersifat spesifik karena berkaitan dengan wewenang pemerintahan, dalam kepustakaan hukum Belanda populer dengan sebutan specialiteits beginsel.

Dari segi substansi dapat diterjemahkan dalam bahasa hukum Indonesia dengan asas "Tujuan".

Asas legalitas yang dikenal dalam asas rechts staat, oleh karena itu menjadi landasan bagi kewenangan pemerintah untuk bertindak dengan dikaitkan pada suatu tujuan.

Setiap kewenangan pemerintah (bestiacrs beveogdheid) diatur oleh peraturan per-Undang-undangan dengan suatu tujuan tertentu dalam kaitannya dengan :

A. Pembentukan Hukum 
1. Peningkatan pembaharuan hukum (yang lama) secara terarah dan terpadu kepada kodifikasi dan unifikasi bidang-bidang tertentu.

2. Penyusunan peraturan per-Undang-undangan bam untuk mendukung pembangunan sesuai tuntutan pembangunan, kesadaran hukum dan dinamika yang berkembang dalam masyarakat.

3. Ditingkatkan penyediaan sarana dan prasarana yang diperlukan serta ditingkatkan pendayagunaannya.

B. Bidang penerapan dan pelayanan hukum

1. Pemantapan kedudukan, fungsi hukum pranata pejabat, penerapan dan pelayanan hukum sesuai dengan wewenang dan kewajiban masing-masing berdasarkan UUD dan peraturan yang berlaku.

2. Pemantapan sikap dan perilaku para pejabat penerapan dan pelayanan hukum.

3. Peningkatan citra, wibawa dan keterampilan/ kemampuan yang profesional dari aparat penerap dan pemberi pelayanan hukum.

4. Pengaturan hukum yang sederhana, efisien (deregulasi).

5. Administrasi pelayanan hukum yang tertib dan sederhana. efisiensi (debirokratisasi).

6. Ditingkatkan penyediaan sarana dan prasarana yang diperlukan serta ditingkatkan pendayagunaannya.

C. Bidang pencagakan hukum

1. Pemantapan kedudukan, fungsi dan pranata pejabat, penegak hukum sesuai dengan wewenang dan kewajibannya masing-masing berdasarkan UUD 1945 dan peraturan yang berlaku.

2. Pemantapan sikap perilaku aparat penegak hukum.

3. Peningkatan citra, wibawa, kemampuan, keterampilan yang profesional dari aparat penegak hukum pada umumnya

4. Peningkatan fungsi yurisprudensi.

5. Penyederhanaan proses peradilan agar lebih sederhana, cepat dan tepat dengan biaya yang terjangkau oleh seluruh lapisan masyarakat.

6. Dimantapkan penyelenggaraan pemberian bantuan hukum dan konsultasi hukum bagi lapisan masyarakat yang kurang mampu.

7. Pemantapan pemberian penyuluhan hukum

Pembinaan sikap perilaku aparat penegak hukum harus mengarah kepada pembinaan abdi hukum yang mengayomi masyarakat, jujur bersikap tegas dan adil.

Demikian juga penyuluhan hukum agar anggota masyarakat menyadari dan menghayati hak dan kewajiban asasi anggota masyarakat dalam rangka :

- Tegaknya hukum

- Tegaknya keadilan

- Perlindungan terhadap harkat dan martabat manusia

- Adanya ketenteraman dan kepastian hukum

- Adanya ketertiban hukum 
- Terbentuknya sikap perilaku yang taat pada hukum

\section{Indonesia Negara Hukum yang Sedang Berkembang}

Indonesia sebagai negara hukum yang sedang berkembang sudah setengah abad lebih merdeka, masih menghadapi banyak masalah di dalam hal penegakan hukum. Transisi dari pemerintahan orde bam yang otoriter kepada orde reformasi yang belum jelas program, dan sasaran reformasinya. Transisi sudah berjalan 4 (empat) tahun hanya kebebasan berbicara dan mengemukakan pendapat dan kebebasan pers yang sudah dirasakan.

Kebiasaan mengemukakan pendapat dan kebebasan pers masih tidak percaya, pemerintah jatuh bangun, resuffle kabinet tidak menentu.

Di hampir semua provinsi dan kabupaten berganti unjuk rasa. Semua ini berakibat ekonomi goyah, harga turun naik, penegakan hukum tidak ada, dampak negatif dari sistem pemerintahan sentralisasi ke desentralisasi yang

sedang mengalami transisi tidak dirasakan. Di samping itu sebagai negara yang sedang berkembang beberapa masalah yang menonjol yang sulit diatasi antara lain:

1. KKN (korupsi, kolusi, nepotisme) di semua daerah provinsi, kabupaten pada semua tingkat dan kesempatan belum terpecahkan (penegakan hukumnya).

2. Otorisasi berlebihan di semua provinsi dan kabupaten, belum siap dan matang perencanaannya sehingga penggunaan dana tidak terarah maka terjadi pemborosan di semua kabupaten.

3. Tidak ada pertanggungjawaban secara transparan, rakyat sendiri bingung kemana arah reformasi yang didengung-dengungkan selama ini, rakyat/mahasiswa menjadi korban orang yang berteriak mengaku pemimpin reformasi yang menikmati.

4. Kondisi sepeti ini menimbulkan kebijaksanaan pemerintah tidak efisien. Kelemahan utama hukum perundang-undangan dimana kegagalan dalam mengungkap dengan jelas hubungan sebab-akibat UU dengan pembangunan.

Selama pemerintahan orde bam dibawah UUD 1945 yang dikeramatkan (sakral) penyimpangan dan penyalahgunaan wewenang ada di pusat pemerintahan sekarang sudah hijrah kepada raja-raja kecil di kabupaten, adapun bentuk penyimpangan/penyalahgunaan wewenang itu antara lain :

1. Suap: dimana pejabat menerima nilai tertentu karena telah menggunakan kewenangannya, baik dalam lingkup kewenangannya yang syah demi kepentingan orang yang menyuapi.

2. Penggelapan: seorang pejabat menggunakan wewenang untuk membeli barang (jasa) dengan harga yang murah kemudian menjualnya dengan harga yang lebih mahal dengan cara mengambil keuntungan untuk din sendiri.

3. Kolusi : seorang pejabat menggunakan wewenangnya memberikan pekerjaan (organisasi) individu karena alasan keluarga.

4. Perkaya diri sadar atau tidak sadar dengan menggunakan wewenangnya yang resmi seorang pejabat mengambil keputusan yang berhubungan dengan keuangan untuk kepentingan pribadinya. Bentuk-bentuk penyimpangan dan penyalahgunaan wewenang dalam era reformasi sekarang ini harus menjadi sasaran utama menegakkan reformasi hukum dimana para pejabat pengambil keputusan wajib mempertanggung jawabkan tindakan mereka. Pertanggungjawaban atas permintaan seorang 
pejabat/yang lebih tinggi suatu Lembaga wajib memberikan penjelasan yang memuaskan tentang suatu keputusan. Pertanggungjawaban secara transparan diperlukan agar Lembaga masyarakat mengetahui secara teratur tentang tata cara bekerjanya dan keputusan-keputusan pejabat.

Bentuk pertanggungjawaban yang diperlukan ialah :

1. Pertanggungjawaban keuangan kepada lembaga-lembaga terkait. Pertanggungjawaban atas keputusan-keputusan yang telah diambil Pertanggungjawaban kegiatan yang berjalan

2. Pertanggungjawaban bila ada yang dirugikan

3. Pertanggungjawaban keatas secara hirarkis

4. Pertanggungjawaban kebawah kepada yang berkepentingan Semua pertanggungjawaban adalah dalam rangka supremasi hukum di dalam suatu negara hukum.

\section{KESIMPULAN}

Lemahnya penegakan hukum dalam negara hukum Indonesia merupakan suatu ciri negara yang sedang berkembang masih mencari bentuk sendiri.

Untuk menciptakan pembangunan yang efektif dan pemerintah yang bersih berdasarkan supremasi hukum dengan meningkatkan kemampuan dan wibawa penegak hukum di samping menertibkan fungsi lembaga-lembaga hukum menurut proporsinya masing-masing.

Pemupukan kesadaran hukum dalam masyarakat dan membina sikap para penguasa dan para pejabat pemerintah kearah penegakan hukum keadilan serta perlindungan terhadap harkat dan martabat manusia dan ketertiban serta kepastian hukum sesuai dengan UUD 1945.

Pembangunan dibidang hukum negara hukum Indonesia didasarkan atas landasan tertib hukum sepeti yang terkandung dalam Pancasila dan UUD 1945.

Pembangunan dan pembinaan hukum diarahkan agar hukum mampu memenuhi kebutuhan keadilan dan keseimbangan (equilibrium) sesuai dengan tingkat kemajuan pembangunan di segala bidang sehingga dapat diciptakan ketertiban dan kepastian hukum dan memperlancar pelaksanaan pembangunan disemua bidang. 


\section{DAFTAR PUSTAKA}

Abdurrahman, SH., MH., Perkembangan Pemikiran Tentang Pembinaan Hukum Nasional di Indonesia, Edisi Petama CV. Akademika Presidento.

Daniel. F.I. LEV. Hukum dan Politik di Indonesia Kesinambungan dan Perubahan, LP3ES.

Mahfud MD., Prof, Dr. SH., MS., Pergulatan Politik dan Hukum di Indonesia.

Mahfud MD., Prof, Dr. SH., MS., Politik Hukum di Indonesia, P3ES.

Yamin II. Mr. Prof, Naskah Pesiapan Undang-Undang Dasar 1945 Jilid III, tahun I960.

Wahyono S.H. Prof, 1989. Pembangunan Hukum di Indonesia, Cetakan Pertama,.

Hadjon SH., Prof, Dr. dan Tatiek Sidjatwati Dr., SH., MS., 2002. Good Govermance dalam Penyelenggaraan Pemerintahan Daerah.

R. Wiyono S.H. Tindak Pidana Korupsi di Indonesia.

Risalah Sidang Badan Penyelidik Usaha-usaha Persiapan Kemerdekaan Indonesia (BPUPKI) Panitia Persiapan Kemerdekaan Indonesia (PPKI).

SP. Marbanu, Dena Kamelus, CS, Dimensi-Dimensi Pemikiran Hukum, Administrasi Negara, UII Press Yogyakata.

Undang-Undang Dasar Tahun 1945. 